James Madison University JMU Scholarly Commons

Libraries

Libraries \& Educational Technologies

$12-31-2016$

\title{
Reference Services in Liberal Arts Libraries
}

Emma R. Oxford

James Madison University, oxforder@jmu.edu

Follow this and additional works at: http://commons.lib.jmu.edu/letfspubs

Part of the Library and Information Science Commons

\section{Recommended Citation}

Oxford, E. (2016). Reference service in liberal arts libraries. Journal of New Librarianship, 1(1), 3-27. doi:10.21173/newlibs/2016/ 1/oxford.1

This Article is brought to you for free and open access by the Libraries \& Educational Technologies at JMU Scholarly Commons. It has been accepted for inclusion in Libraries by an authorized administrator of JMU Scholarly Commons. For more information, please contact dc_admin@jmu.edu. 


\section{Reference services in liberal arts libraries}

\section{Emma Oxford}

Libraries \& Educational Technologies, James Madison University

Abstract: This study addresses a gap in the literature regarding reference services at liberal arts institutions. The author conducted a literature review to examine the existing body of research on reference services and distributed a survey to the 80 member libraries of the Oberlin Group in February 2015. The study found that a wide range of reference practices are in place at liberal arts libraries and focused especially on the use of a designated reference desk, which is widespread. However, there is a correlation between higher librarian satisfaction with reference services and the absence of a desk. Comments from respondents are included in the discussion and reflect common themes around reference services. Some limitations of the study include its small sample size and conflicting responses from librarians at the same institution. Nevertheless, this article provides a starting point for further research into liberal arts reference. The factors relating to librarian satisfaction, the themes running through the comments, and the trends discussed in the literature review may be relevant for determining the most effective reference model at any institution.

Keywords: academic libraries, liberal arts, reference desk, reference services

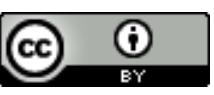

This is an Open Access article distributed under the terms of the Creative Commons Attribution 4.o International License (http://creativecommons.org/licenses/by/4.o), which permits unrestricted use, distribution, and reproduction in any medium, provided the original work is properly cited. 


\section{Introduction}

Reference is a key part of library service at all academic institutions. Yet while studies abound on almost all aspects of reference, few consider reference services specifically at liberal arts institutions. Institution type has been identified as a possible factor in reference trends (Applegate, 2008; Yang \& Dalal, 2015), so the dearth of research on liberal arts reference is a significant gap in the literature. This study addresses that gap through a survey of a group of liberal arts libraries in the United States.

The motivation for this study begs the question: why does the profession need research on reference services in the liberal arts? Given the profound impact liberal arts institutions have had on trends in higher education, it seems likely that liberal arts' reference would be relevant on a wider scale. For example, Evan Farber, longtime College Librarian at Earlham College, was an early champion of bibliographic instruction (Farber, 1974, 1999). Universities of all types now make use of that concept. Faculty at Oberlin and Bowdoin Colleges were also early adopters of bibliographic instruction courses (Tucker, 1980). Liberal arts colleges, more so than their research-oriented counterparts, are teaching institutions. Trends in instruction-based practices, including reference, are likely to emerge from these institutions. Therefore, current practices in liberal arts libraries are relevant to the wider library literature.

\section{Research Questions}

This study addresses three main research questions:

1. What are the current reference practices in use at liberal arts institutions?

2. What are the trends at liberal arts libraries regarding the use of a reference desk? 
3. How satisfied are liberal arts librarians with the reference services provided at their institution, and are there certain factors that correlate with their satisfaction? These questions aim to generate a comprehensive picture of reference services in the liberal arts but with a special focus on the presence or absence of a designated reference desk and its impact on librarians' perspectives of reference services. A popular belief is that libraries are experiencing a crisis, or at least a shift, in reference. Do individual librarians perceive this? Whatever the prevailing opinion of their patrons, librarians are the ones implementing changes in their libraries, so their perspectives are relevant when examining trends in reference services.

For the purposes of this study, the term reference services refers to the entire suite of methods an academic library uses to provide reference to its patrons. The term reference practices is used almost interchangeably with reference services but refers more to the specific technologies in place that make up reference services at an academic library.

These research questions were addressed through a comprehensive literature review and a survey (Appendix) emailed to a group of liberal arts libraries in the United States.

\section{Literature Review}

There have been several studies on trends and best practices in reference services at academic libraries, with many focusing on a long-established symbol of library reference: the reference desk. The discussion on whether libraries should have a designated reference desk staffed by librarians goes back decades. Boyer and Theimer 
(1975, p. 195) reported that in a survey of 141 academic libraries at institutions of varying size, 10 indicated that they did not have a separate reference desk. This means that four decades ago, roughly seven percent of the surveyed academic libraries had either done away with their reference desk or had never had one to begin with. A decade later, Ford (1986, p. 492) raised many issues about the desk that are still pertinent today, pointing out that even then, "Much that is written indicates that the reference desk does not provide the most effective and efficient service, and therefore we must consider alternatives." She also pointed out that one reason librarians may be reluctant to relinquish the desk has nothing to do with the desk's effectiveness but comes from the perception that a reference desk is a "sacred library tradition" (p. 491)

Ford's (1986) sentiment is echoed in more recent studies as well. At Dickinson College, after much discussion, the library removed its physical reference desk in 2007. There were many concerns throughout this process, but "of most concern, and most difficult to address, was the removal of a powerful symbol of librarianship and library service" (Arndt, 2010, p. 74). Indeed, many library staff equated the reference desk with reference services as a whole: how could you have one without the other? Removing the reference desk at Dickinson's library was largely successful, as, among other things, the number of "true reference questions" fielded by librarians increased, while directional questions decreased (Arndt, 2010, p. 77).

Some institutions have eliminated their reference desk out of practical or financial necessity rather than a deeper consideration of best practices. The library at University of California, (UC) Merced, built in 2005, has never had a reference desk (Davidson \& 
Mikkelsen, 2009). Although this decision was born out of practical necessity, the librarians felt that not having a desk fit with their library's values, saying, "We value our librarians as managers who work on broad solutions and effectively use their expertise. To have time to dedicate to larger challenges and projects, we decided that staffing a traditional reference desk multiple hours a day was probably not the best use of our time" (Davidson \& Mikkelsen, 2009, p. 351). Their reasoning suggests that in some cases, a reference desk may be a barrier to effective service rather than a hallmark of it.

Other trends include using students to staff the reference desk rather than eliminating it completely. In 2010, at Kimbel Library at Coastal Carolina University, the reference desk moved to a peer reference model, making use of reference student assistants (RSAs) rather than librarians (Faix et al., 2010). Like the decision at UC Merced, this decision came on the heels of "budget cuts, severe time and staffing limitations, and increasing demands for library services" (Faix et al., 2010, p. 90). However, unlike the librarians at UC Merced, those at Kimbel did not seem to believe that using RSAs was the ideal reference model, as when financial constraints were loosened, they moved back to having a librarian "on call" during reference hours (Faix, 2014). It should be noted, though, that during the time when the desk was almost exclusively staffed by RSAs, librarians found that the model was effective. A patron survey indicated that "the overwhelming majority of patrons" found the RSAs helpful, and an RSA survey indicated that the student workers themselves had a positive view of the experience (Faix et al., 2010, pp. 310, 312). 
More common than staffing the desk with students is staffing the desk with nonlibrarian library staff. A survey conducted by Banks and Pracht (2008) of 101 academic libraries in the United States found that a majority of libraries used "non-degreed" personnel at the reference desk. This result is not new: Boyer and Theimer (1975, p. 199) found in their survey of 141 academic libraries that the use of nonprofessionals at reference desks was widespread.

Other types of reference services, especially virtual reference, have also been examined at academic libraries. Kayongo and van Jacob (2011) examined late-night chat service at Hesburgh Library at the University of Notre Dame, which was well-used during the two and a half years it was available. Due to staffing constraints, Hesburgh Library eventually had to discontinue this service, but their case study provides a good example of how considerations unrelated to the value of a service affects reference practices other than the desk (Kayongo \& van Jacob, 2011, p. 108). In another case study, librarians at the University of Texas at San Antonio (UTSA) considered the potential value of "proactive" chat services (Kemp, Ellis, \& Maloney, 2015; Maloney \& Kemp, 2015). These text-entry boxes can be embedded on library websites so that they appear and prompt the user to chat with a librarian at opportune times (e.g., after a user has spent more than a minute on a given webpage). The UTSA librarians found that using a proactive chat service increased the number of questions received via chat. Additionally, through a review of previous studies on virtual reference, they suggested that proactive chat services in general may be an effective way for libraries to counter the declining number of questions received in the physical environment (Kemp et al., 2015; Maloney \& Kemp, 2015). Yang 
and Dalal (2015) also examined chat services and other types of virtual reference in their comprehensive study of reference at academic libraries. They found that most institutions provided some type of virtual reference service, but the type and number of services offered depended on other institutional characteristics (pp. 72, 78).

The effect of institution type on reference services has been examined elsewhere in the literature as well. For example, Applegate (2008) conducted a study on the differences in reference transaction statistics between 2002 and 2004 by institution type based on evidence that "ARL experiences may be disproportionately affecting the representation of the 'decline' issue" (Applegate, 2008, p. 176). Her results indicated that the type of academic institution is relevant when examining trends in reference transactions. According to her results, from the perspective of an individual librarian, only librarians at ARL institutions have experienced a decline in the number of reference transactions they answer per week, and even in absolute terms, the number of reference transactions has not declined as drastically at private masters and baccalaureate institutions as it has at ARL institutions (Applegate, 2008, pp. 182-183). On the other hand, others have observed that trends are in fact similar across institution type (Boyer \& Theimer, 1975, p. 195). These discrepancies underscore the need for further investigation into reference at institutions underrepresented in the literature.

One underrepresented group is those at liberal arts college libraries. Even Applegate (2008), who identified four distinct institution types (ARL, Doctoral-NonARL, Master's, and Baccalaureate) did not specifically consider liberal arts colleges in her study. Other studies that examine multiple academic institutions purposely exclude non- 
ARL institutions (Arant \& Benefiel, 2002; Jackson, 2002; Martell, 2008) or draw distinctions based only on institution size (Banks \& Pracht, 2008). What is lacking from these analyses is a comprehensive look at any aspect of reference services in the liberal arts. The research that does exist on liberal arts reference frequently takes the form of case studies at specific libraries (Arndt, 2010; Faix, 2014; Faix et al., 2010). Comparisons of liberal arts libraries and examinations of trends across institutions are especially lacking.

\section{Methods}

A survey (Appendix) was distributed via the library directors' listserv of the Oberlin Group libraries. The 8o members of the Oberlin Group are liberal arts institutions in the United States, varying in size and location. A full list can be found on the Oberlin Group website ${ }^{1}$. They were chosen as a sample group because they were easy both to identify as liberal arts colleges and to get in touch with. As the author was a librarian at one of the Oberlin Group institutions at the time the study was conducted, it also seemed likely the response rate would be higher than if the survey were sent to a random group of libraries. One hundred, thirty-seven responses were received. Sixteen of the responses were deemed unusable, mostly because they were incomplete, making for 121 responses from 60 distinct institutions, or a response rate of 75 percent (6o out of 80 institutions).

The survey was distributed at the end of February 2015. Library directors were encouraged both to complete the survey themselves and to forward it to other librarians at their institution, as more than one response per institution was allowed. A reminder

\footnotetext{
${ }^{1} \underline{\text { http://www.oberlingroup.org/group-members }}$
}

Journal of New Librarianship, 1 (2016) pp·3-27 
email was sent out in early March, which resulted in a few additional responses, and the survey was closed in mid-March 2015.

\section{Results}

Thirty-one Library Directors, 59 Reference Librarians, and 31 participants identifying their role as "Other" responded to the survey. For the purposes of this study, Reference Librarian indicated anyone who participates in any aspect of reference services at their library. Although the survey attempted to make this definition clear, it is likely some respondents misinterpreted the question, as Reference Librarian is most often associated with a specific job title. Many of the results of this study focused on librarians' opinions of their work and their institution, so for consistency's sake, self-reporting was used to identify librarians' roles, rather than having the researcher interpret their explanations. Thus, if a respondent indicated that they identified as Other, even if their subsequent comments suggested that they participated in reference services, they were still counted as Other in the survey results.

Respondents were asked to identify which reference practices were in place at their institution. The 121 respondents came from 60 distinct institutions, so for many institutions there were multiple responses. If any respondent indicated that a specific reference practice was in place at their institution, then that institution was counted as having that reference practice. Table 1 lists the practices asked about in the survey (with the exception of the use of a designated reference desk, which was examined separately) and the number of libraries identified as providing that type of reference. "Single point of service" refers to a service point designed to answer both circulation and reference 
questions, as well as potentially other queries. None of the eight respondents who selected "Other" elaborated on what they meant.

Table 1

Reference Practices at Oberlin Group Libraries

Practice

Consultation/appointments with librarians Number of Institutions

E-mail reference 59

Chat reference 58

Drop in office hours

47

Text reference 38

Single point of service 29

Asynchronous, online reference modules

19

Reference in other locations

19

Consultation/appointments with library staff 8

Other

8

Roving reference in library/libraries

Consortial reference service

5 3

Table 1. Number of institutions (out of 6o) where at least one respondent indicated a given practice was in use.

Respondents were asked additional questions regarding the presence of a designated reference desk at their institution and (if such a desk existed) its staffing model and hours. A designated reference desk was defined as a service point where reference transactions (and theoretically, only reference transactions, although it may unavoidably field directional inquiries as well) took place. Since this survey allowed for multiple responses from a single institution, there were a few instances where librarians from the same institution disagreed with each other (or contradicted themselves) to the point that the presence of a desk, its staffing model, or its hours could not be positively determined. Forty institutions were found to have at least one designated reference desk. No institution was positively determined as having more than one designated reference 
desk, although some individual respondents indicated that this was the case. Seventeen institutions were found not to have any designated reference desk, and for three institutions, the presence of a reference desk could not be determined from the survey responses.

Using only responses from the 40 institutions positively identified as having a reference desk, figures 1 and 2 were generated. Figure 1 shows the various staffing models in place at the 40 relevant institutions, and figure 2 shows the weekly hours of the desks. For both staffing model and hours, there were some libraries where this information could not be determined from the survey responses.

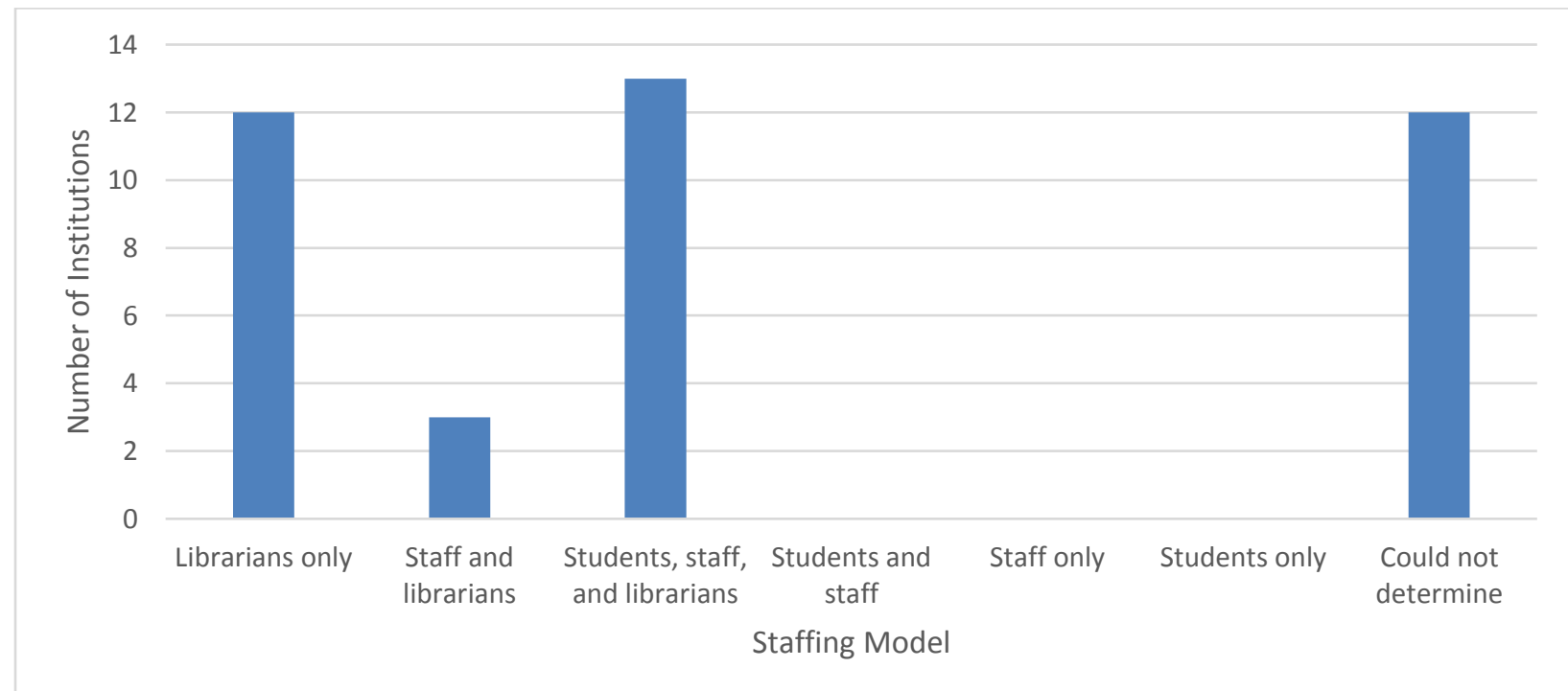

Figure 1. Reference desk staffing models used by 40 Oberlin Group institutions with a reference desk. 


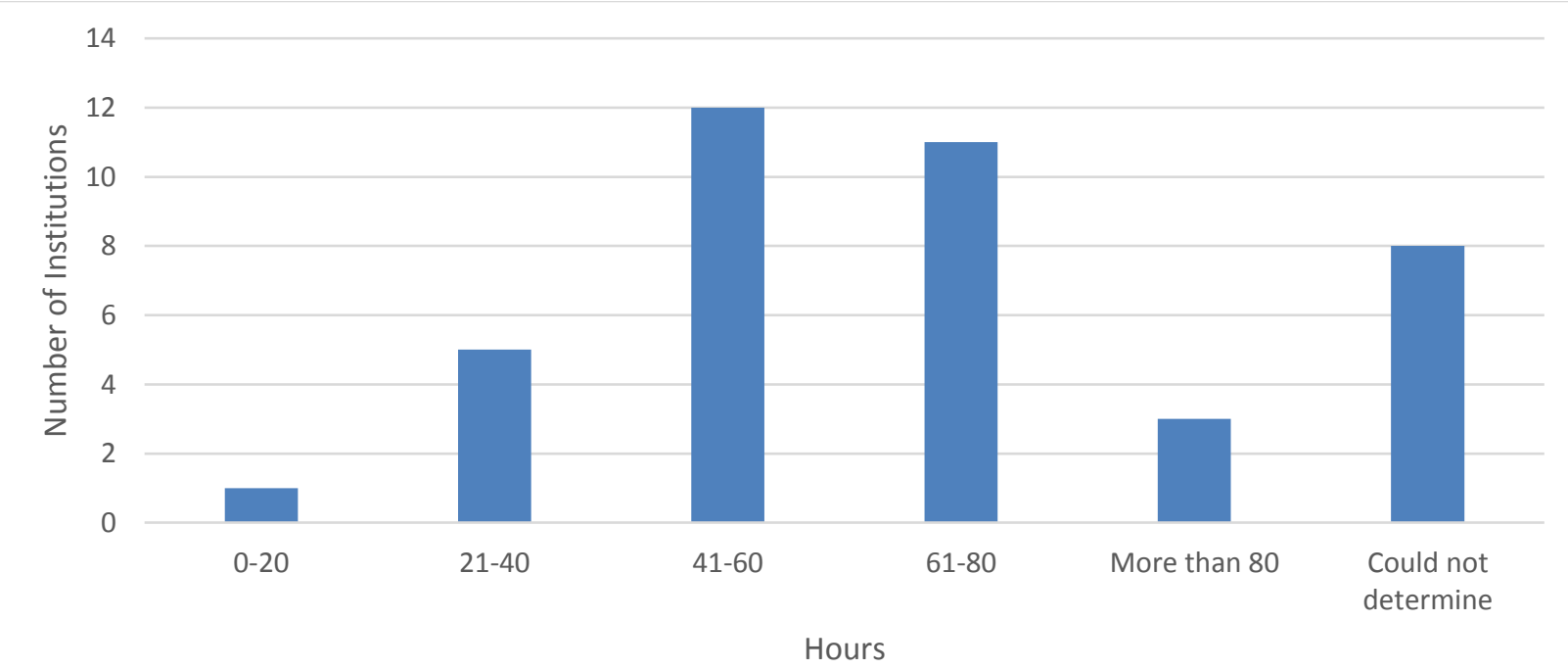

Figure 2. Regular weekly reference desk hours at 40 Oberlin Group institutions with a reference desk.

Respondents were also asked to indicate how satisfied they were with reference services in their library. Satisfaction was correlated with several factors, including a respondent's role in the library, the presence of a reference desk at their institution, and whether they believed their institution had plans to change its reference model. No statistical correlations were performed, and in most cases the sample size was too small for such analyses to have been meaningful.

Table 2 shows the satisfaction ratings by type of respondent for the 121 total respondents. Table 3 shows satisfaction ratings for respondents at 40 institutions with a reference desk and 17 institutions without a reference desk. Responses from the three institutions where the presence of a desk could not be determined were not included.

\begin{tabular}{|lccc|}
\hline \multicolumn{4}{l}{ Table $\mathbf{2}$} \\
\multicolumn{4}{l}{ Respondent Satisfaction by Role } \\
\hline Satisfaction Rating & Library Directors & Reference Librarians & Other \\
Very Satisfied & $6(19 \%)$ & $8(14 \%)$ & $6(19 \%)$ \\
Satisfied & $15(49 \%)$ & $33(56 \%)$ & $10(32 \%)$ \\
Neutral & $6(19 \%)$ & $12(20 \%)$ & $8(26 \%)$
\end{tabular}




\begin{tabular}{|lccc|} 
Dissatisfied & $4(13 \%)$ & $6(10 \%)$ & $5(16 \%)$ \\
Very Dissatisfied & $\underline{0}$ & $\underline{\mathbf{0}}$ & $\underline{\mathbf{2}(7 \%)}$ \\
& $31(100 \%)$ & $59(100 \%)$ & $31(100 \%)$ \\
\hline
\end{tabular}

Table 2. Satisfaction with institution's references services of all 121 respondents correlated with selfidentified role in library.

\begin{tabular}{|lcc|}
\hline \multicolumn{4}{|l|}{ Table 3} & \\
\multicolumn{4}{|l|}{ Respondent Satisfaction by Presence of Desk } & $\underline{\text { No Desk }}$ \\
\hline Satisfaction Rating & $\underline{\text { Desk }}$ & $9(33 \%)$ \\
Very Satisfied & $11(13 \%)$ & $14(52 \%)$ \\
Satisfied & $40(45 \%)$ & $3(11 \%)$ \\
Neutral & $21(24 \%)$ & $1(4 \%)$ \\
Dissatisfied & $14(16 \%)$ & $\underline{0}$ \\
Very Dissatisfied & $\underline{2(2 \%)}$ & $27(100 \%)$ \\
& $88(100 \%)$ & \\
\hline & & \\
Table 3. Satisfaction with institution's references services of 115 respondents from 57 institutions where \\
presence (40 institutions) or absence (17 institutions) of a desk was positively determined.
\end{tabular}

There appears to be a correlation between not having a reference desk and satisfaction with reference services at a liberal arts library. Some respondents provided comments elaborating on their ratings. Reasons for keeping the desk, reactions to eliminating it, and other opinions varied widely, but some common themes included:

- The possibility of using student workers,

- Concern for librarians' time,

- The question of the reference desk as an important, symbolic library tradition,

- The role that institutional culture plays on decisions about reference services,

- The importance of librarian visibility and reaching all users, and

- The value of reference practices that allow for in-depth research questions to come to librarians.

Journal of New Librarianship, 1 (2016) pp.3-27 
Lastly, satisfaction was correlated with a respondent's indication that their institution did or did not have plans to change its reference model. Respondents from the same institution sometimes disagreed about whether their institution had such plans. However, since this was a more subjective question, responses were considered individually rather than along institutional lines. Thirty respondents indicated that their institution did have plans to change its model, while 91 respondents said their institution did not. Respondents who believed their institution had plans to change its reference model were more likely to be dissatisfied with current reference services, while respondents who did not believe changes were forthcoming were much more likely to be satisfied or very satisfied with current services. Table 4 compares their responses.

\begin{tabular}{|lcc|}
\hline \multicolumn{4}{|l|}{ Table 4} & \\
\multicolumn{4}{l}{ Respondent Satisfaction by Plans to Change Reference Model } \\
\hline Satisfaction Rating & \multicolumn{1}{l|}{ Plans to Change } & No Plans to Change \\
\hline Very Satisfied & $2(7 \%)$ & $18(20 \%)$ \\
Satisfied & $10(33 \%)$ & $48(53 \%)$ \\
Neutral & $9(30 \%)$ & $17(18 \%)$ \\
Dissatisfied & $8(27 \%)$ & $7(8 \%)$ \\
Very Dissatisfied & $\underline{1(3 \%)}$ & $1(1 \%)$ \\
& 30 & 91 \\
\hline & & \\
Table 4. Satisfaction with institution's references services of all 121 respondents correlated with whether \\
they believed their library had plans to change its current reference model.
\end{tabular}

It should also be noted that respondents at 16 of the 17 institutions currently without a reference desk indicated that there had previously been a designated reference desk at their library. Four institutions eliminated their desk within the past two years, while 10 said their desk was eliminated two to five years ago, and one indicated the desk was eliminated more than five years ago. One institution did not identify when their desk 
was eliminated or if one ever existed. The sample sizes in this case were too small to examine any type of correlation between how long ago the desk was eliminated and the respondents' satisfaction ratings.

\section{Discussion}

\section{Research Question 1}

This study's first research question asked about current reference practices in use at liberal arts institutions. As shown in table 1, many types of practices are in use, with the three most common being consultations/appointments with librarians, e-mail reference, and chat reference. (A designated reference desk, not shown in that table, would come in fourth.) It is worth remarking that two of these top services are electronic and do not rely on the traditional face-to-face model of reference. The prevalence of virtual reference services, especially chat services, is in line with findings from the University of Texas at San Antonio (USTA), which suggest that such services can increase the number and complexity of reference questions (Kemp et al., 2015; Maloney \& Kemp, 2015). Like their ARL counterparts, Oberlin Group institutions may also be observing that these are the most effective ways to get patrons to engage with librarians.

\section{Research Question 2}

The second research question asked about trends regarding the use of a reference desk at liberal arts libraries. Based on this study, use of a reference desk is still widespread, with 40 of the 60 responding institutions identified as having one. However, $17(28.3 \%)$ of the libraries were found not to have a designated reference desk - much higher than the seven percent observed several decades ago (Boyer \& Theimer, 1975, p. 
195). Fourteen of these libraries eliminated their desk in the past five years, four in the past two years. If there is a trend toward eliminating the reference desk at liberal arts libraries, it is recent and slow-going. But even libraries who have no plans to eliminate their desk should take note that across the board, satisfaction with reference services is higher among librarians at institutions that do not have a designated reference desk, a result discussed below.

Results also indicate that staffing models and hours of reference desks vary widely. The most common staffing model is a desk staffed by students, staff, and librarians (figure 1). The widespread use of library staff is consistent with previous studies that address this question (Banks \& Pracht, 2008; Boyer \& Theimer, 1975). However, it is worth noting that the use of staff and librarians is less common than the use of staff, librarians, and students ( 3 out of 40 libraries vs. 13 out of 40 libraries). Many respondents commented on the training of student workers, both in libraries currently using this model and those looking to implement it. Some representative comments included:

1. We have a service point located next to Circulation. It is staffed by librarians, paraprofessionals, and a specially trained student.

2. I think the mix of a dedicated reference desk staffed by library staff and trained students works well in combination with library staff being available for in-person and email consultations. We're a small school, but I feel like this approach allows us to reach across our community by providing options that work for different students.

3. I think our Reference staffing hours should be reanalyzed, and I would also like to look into training student workers to help staff the desk.

The emphasis on "specially trained" student assistants working alongside librarians or staff was a common theme, which echoes some of the existing literature (Faix et al., 
2010). The hours reference desks were staffed also varied, although the majority ( 26 out of 40) were staffed at least 41 hours a week (figure 2). This is especially significant given that the burden a reference desk places on librarians' time was a theme in the comments. Some comments included:

1. We are always trying to determine what is the best use of reference librarians' time.

2. We are considering a single service desk model (ref/circ/info etc. all at one desk) with reference librarians on call.

3. We're thinking of combining service points (Reserve, ILL, Circ, basic Reference) into one desk. Staffing the current Ref desk with librarians often isn't a good use of their time.

These comments are reminiscent of Davidson and Mikkelsen (2009), who cited considerations for librarian time as a reason UC Merced never had a reference desk. This concern may be a driving factor behind the push to use student employees. Interestingly, only one respondent commented that activities which waste a librarian's time may waste a student worker's time as well:

We see more in-depth questions in one-on-one situations. Thus our student workers are getting bored and its [sic] more work to keep them busy along with part-time staff when all we really need is basic coverage. Therefore we hope to combine the reference and circulation desk so reference workers can keep busy with other tasks when not helping with research.

This comment also provides some insight into this study's first research question, discussed above. If librarians see "more in-depth questions in one-on-one situations," perhaps this explains why consultations/appointments with librarians is the most commonly offered reference service: this is the practice through which "real" reference and research questions most often come to the library. 


\section{Research Question 3}

This study's third research question addressed librarian satisfaction with reference services. Overall, respondents' satisfaction did not correlate strongly with their role in the library. Library Directors and Reference Librarians were especially close in their satisfaction ratings, with $68 \%$ of Library Directors and $69 \%$ of Reference Librarians indicating that they were either satisfied or very satisfied with reference services at their institution. Similarly, 13\% of Library Directors and 10\% of Reference Librarians reported being dissatisfied with reference services. On the other hand, a higher percentage of respondents identifying as Other reported being neutral, dissatisfied, or very dissatisfied with reference services (49\%). A higher proportion of neutral respondents may be because librarians whose roles in the library are less connected with reference are less likely to have strong opinions on these services. A higher percentage of dissatisfied or very dissatisfied respondents may also relate to their more objective view - perhaps librarians who are not as involved in reference perceive problems with their institution's current model more acutely and are more willing to address them. Alternatively, perhaps their dissatisfaction is more rather than less personal, as they may perceive the reference work they do engage in as a burden, taking time away from their "real" job in the library. Further research into how reference work is divided among librarians at different libraries and how this impacts reference services may be warranted.

While respondent satisfaction was mostly independent of role, it did correlate with the presence or absence of a designated reference desk. At the 17 institutions without a reference desk, $85 \%$ of respondents reported being either satisfied or very satisfied with 
reference services, compared to $58 \%$ at the 40 institutions with a desk. Comments made by librarians from institutions without a reference desk included:

1. I can't believe how glad I am to be shot of the reference desk. No more spending ten hours a week fixing printers and pointing to the circ desk!

2. I don't think anyone here misses the reference desk. It was hard to find and took people away from other responsibilities.

3. Merging our reference desk (which was in a different room that was quite intimidating) with our instructional technology/circulation/public services desk was one of the best moves we've made in the past 4 years. We are significantly more visible to the college community, we work closer with our colleagues, we have broken down that weird thing about MLS vs. non-MLS folks that runs rampant in libraries [...]. At the same time that we merged those desks, we also saw an increase in the number of consultations we were doing.

4. Because we are a merged desk, our reference and instructional technology partnerships are significantly stronger than when we had multiple desks.

These comments point to a couple of dimensions of merged service that this study did not explicitly examine but that are interesting to consider: firstly, the working relationship between reference librarians and others in the library and secondly, the impact of building layout on the reference desk. In libraries where the reference desk is "hard to find" or "quite intimidating," merging it with other service points may be more logical than in libraries with more open layouts. This could be another area in which to compare liberal arts libraries with each other and with other institutions: is it the type of institution that has the greatest effect on reference transactions, or is it the geography of the library? Other respondents remarked that the quality of reference questions improved when the physical reference desk was removed, for example: 
When we went from a Reference Desk to a Consultation Area we found the length and quality of the reference interactions with students increased.

This remark echoes Arndt's (2010, p. 77) observation that removing the reference desk at Dickinson's library led to an increase in the number of "true reference questions" librarians fielded. A couple respondents, including one quoted above, commented on the types of technical questions, such as printer help, that can come to a reference desk. Removing the reference desk and creating a different channel for true reference and research questions to come to librarians seems to eliminate these non-reference questions. All of these comments point to potential factors in the increased librarian satisfaction at libraries without reference desks. However, further research is warranted to determine if there are other factors in play at institutions without a desk that could also be contributing to the higher satisfaction ratings.

The results also indicated a correlation between an institution's plans to change its reference model and librarian satisfaction. It is heartening that respondents who indicated their institution had no plans to change its model were more likely to indicate that they were satisfied or very satisfied with the current model, and vice versa. This suggests that at institutions where librarians are dissatisfied with current reference services, there is an impetus to change how reference is done. It is important to note though that factors other than librarian satisfaction, such as tradition or institutional considerations beyond the library, can play a roll in guiding reference services at an institution, including determining whether to staff a reference desk. Respondents reflected on their institution's status as a liberal arts college, the tradition of having a reference desk, the desk's role in librarian visibility, and other aspects of their institution's

Journal of New Librarianship, 1 (2016) pp·3-27 
mission. These considerations were evident at libraries with and without a reference desk. Comments included:

1. We are a liberal arts college. We offer the personal experience. We're not closing our reference desk. It's vital that the faces of librarians are out there every day.

2. Our appointment model seems to resonate well with liberal arts learning and the individualized experience that most of our students seek by coming to a small liberal arts college.

3. I personally don't believe a reference desk should be staffed by anyone who's not a librarian.

4. I look at reference as another opportunity for teaching students-it's like the laboratory for information literacy. It does place another demand on our schedules, but it provides and [sic] important way for us to help further the college's educational mission.

5. We are blending with some of our IT department. Looking in [sic] all models to decide what is best for our institution.

6. We're a largely residential, traditional liberal arts college, which influences the kinds of reference services we offer.

7. The librarians who serve at the desk are adament [sic] that there is symbolic value to having a librarian at the desk.

The value of tradition and institutional considerations clearly mean different things to different libraries: some librarians believe they support a blending of reference with other services or a shift to an appointment model while others see the existence of a reference desk as critical for a liberal arts college. The "symbolic value" of having a reference desk echoes Arndt (2010). She remarked that this was a definite concern when Dickinson College closed its desk, but in spite of this, Dickinson (an Oberlin Group institution) did close its desk and found that it was better for it. Even Ford (1986, p. 491), writing three decades ago, refers to the desk as a "sacred library tradition" which many 
hold onto simply for that reason. These comments also point to some of the ways institution type may play a role in reference services: concerns rooted in an institution's identity as a liberal arts college would not be a factor at other colleges and universities, although the expectations of their own institution may still play a role.

While many respondents expressed concerns that the reference desk was (or had been) a waste of librarians' time, there were comments indicating that the reference desk was a well-used service point at some libraries:

1. We still see a high demand for traditional reference services.

2. We haven't seen a dramatic decline in Reference Desk statistic [sic], and a recent student survey comfirmed [sic] that students remain interested in using drop in research desk help.

3. Our ref desk stats indicate the value of maintaining services. Numbers are down over the years, but complexity of questions is up.

4. We still have a lot of walk-in traffic with real reference questions, particularly in the evenings. We're not even talking about getting rid of the reference desk.

5. We experimented with a service model that relied mostly on appointments (we closed the Research Desk) for a few years. Our numbers dropped precipitously, so we went back to the desk. Our numbers have continued to rise since we made that decision. Students say they know where to find us. They drop by even when they're "not sure if we can help." All librarians agree that we should staff the desk.

This last comment is the only indication from any respondent that an institution closed its desk and reopened it. Clearly the reference desk model continues to work at some institutions, or at least librarians perceive that it is working. This does not change the fact that this study found a noticeable correlation between the absence of a reference desk and librarian satisfaction. However, there are always exceptions to trends, and at 
some institutions the culture, the geography of the library, or some combination of these and other factors may make the reference desk a valuable service point.

\section{Limitations of this Study}

While allowing for multiple responses from each institution was useful in examining librarians' satisfaction with reference services, it did occasionally lead to contradictory information regarding the practices in place at an institution. Respondents from the same institution often disagreed about seemingly basic things such as who staffed the library's reference desk (librarians, staff, or students), how many reference desks the library had, and even how many libraries the institution had. This made comparisons between institutions difficult and necessitated the use of a "could not determine" category when tabulating some of the results. These problems, arising through a combination of the survey design and possibly respondent inattention when completing the survey, were discussed by the researcher in more depth in a short opinion piece (Oxford, 2016).

Another limitation was the small sample size. The Oberlin Group was chosen as the sample frame for this study because the author worked at an Oberlin Group institution, it was easy to distribute the survey to relevant parties, and due to the author's institutional affiliation, it was thought that a higher response rate could be expected and that respondents might be more willing to provide contact information for follow-up. Indeed, this proved to be the case, as 60 out of 80 Oberlin Group institutions were represented in the results, and 81 out of 121 respondents provided contact information for potential follow-up. No respondents were contacted for follow-up regarding the results 
presented here, but contact information may be useful if this data is used for additional research. The Oberlin Group also consists exclusively of liberal arts colleges, so it was a good starting point for a study of this scope. Nevertheless, there are far more than 80 liberal arts colleges in existence, and some of them may be significantly different from any institution in the Oberlin Group.

\section{Conclusion and Suggestions for Further Research}

Definite trends can be seen in reference services at liberal arts institutions, most notably the correlation between higher librarian satisfaction and the absence of a reference desk. Themes in the comments provided by some respondents reflected a wide range of concerns related to reference services. The answer to the question of how best to provide reference clearly varies from institution to institution. Factors from the geography of the library to the institutional culture will play a role in all aspects of reference services, from whether it makes sense to staff a reference desk to the implementation of virtual reference. There are similarities in the types of issues faced by liberal arts libraries, but there can be as much variation as there is similarity in how different institutions deal with the same issue.

Further research should seek to expand the sample size and look at liberal arts colleges outside of the Oberlin Group or to use other classifications, such the Carnegie Classification, to determine trends at specific types of institutions. Additionally, comparisons with studies that have examined reference services at non-liberal arts institutions would be useful for determining whether trends at ARL or other institutions 
are likely to be representative of liberal arts libraries. One respondent commented explicitly that what they are observing matches the current literature on the topic:

We are seeing the common changes in use that other institutions and the literature report. We are not necessarily catering to the whims of 17-21 [year olds], but at the same time we are making accomodations [sic].

It would be worth exploring further if others observed this trend.

Although some respondents touched on this subject in their comments, this study did not explicitly look at trends in number of reference transactions, a common subject in the study of reference at ARL institutions (Applegate, 2008; Banks \& Pracht, 2008; Jackson, 2002; Martell, 2008). This is another topic that could be explored in more depth at liberal arts libraries.

Finally, the discrepancies revealed by allowing for multiple responses from a single institution are worth exploring in and of themselves, as they raise some concerns regarding survey use in general in the library literature. Even if only one person is speaking for an institution, how does the researcher know that the information they relay is accurate? Of course, it is possible some of the discrepancies were due to institutional characteristics that did not fit neatly into any of the categories defined in this study. Further research may also benefit from being strictly qualitative, which would allow the researcher to capture nuances in library design that the mostly multiple-choice survey used here could not account for. Since many of the respondents provided contact information for follow up, a logical next step would be to interview the librarians at institutions for which the responses conflicted and see if any distinct service models and nuances that could explain the confusion start to emerge. 
Reference services are a crucial topic in the library literature. This study was meant to address a lack of information specifically on reference services at liberal arts libraries. Librarians at liberal arts institutions and elsewhere may benefit from this increased understanding of the state of reference in the liberal arts today. However, this study is only meant to be the beginning rather than the end of the discussion, and more research into reference trends in the liberal arts and how libraries can best respond to these trends is warranted. 


\section{References}

Applegate, R. (2008). Whose decline?: Which academic libraries are "deserted" in terms of reference transactions? Reference E User Services Quarterly, 48(2), 176-189. Retrieved from https://journals.ala.org/rusq/article/view/3704

Arant, W., \& Benefiel, C. R. (2002). Hours of operation and service in academic libraries: Toward a national standard. Public Services Quarterly, 1(1), 71-85. http://doi.org/10.130o/J295voino1_o8

Arndt, T. S. (2010). Reference service without the desk. Reference Services Review, 38(1), 71-8o. http://doi.org/10.1108/00907321011020734

Banks, J., \& Pracht, C. (2008). Reference desk staffing trends: A survey. Reference E User Services Quarterly, 48(1), 54-59. Retrieved from https://journals.ala.org/rusq/article/view/3039

Boyer, L. M., \& Theimer, W. C. (1975). The use and training of nonprofessional personnel at reference desks in selected college and universities. College $\mathcal{E}$ Research Libraries, 36(3), 193-200. http://doi.org/10.5860/crl_36_03_193

Davidson, S., \& Mikkelsen, S. (2009). Desk bound no more: Reference services at a new research university library. The Reference Librarian, 50(4), 346-355. http://doi.org/10.108o/02763870903143591

Faix, A. (2014). Peer reference revisited: Evolution of a peer-reference model. Reference Services Review, 42(2), 305-319. http://doi.org/10.1108/RSR-07-2013-0039

Faix, A., Bates, M. H., Hartman, L. A., Hughes, J. H., Schacher, C. N., Elliot, B. J., \&

Journal of New Librarianship, 1 (2016) pp.3-27 
Woods, A. D. (2010). Peer reference redefined: new uses for undergraduate students. Reference Services Review, 38(1), 90-107. http://doi.org/10.1108/00907321011020752

Farber, E. (1974). Library instruction throughout the curriculum: Earlham College program. In J. J. Lubans (Ed.), Educating the library user (pp. 145-162). New York: R. R. Bowker.

Farber, E. (1999). College libraries and the teaching/learning process: A 25-year reflection. The Journal of Academic Librarianship, 25(3), 171-177. http://doi.org/10.1016/Soo991333(99)80196-7

Ford, B. J. (1986). Reference beyond (and without) the reference desk. College $\mathcal{E}$ Research Libraries, 47(5), 491-494. http://doi.org/10.586o/crl_47_05_491

Jackson, R. (2002). Revolution or evolution: Reference planning in ARL libraries. Reference Services Review, 30(3), 212-228. http://doi.org/10.1108/o0907320210435482

Kayongo, J., \& van Jacob, E. (2011). Burning the midnight oil: Librarians, students, and late-night chat reference at the University of Notre Dame. Internet Reference Services Quarterly, 16(3), 99-109. http://doi.org/10.1080/10875301.2011.597632

Kemp, J. H., Ellis, C. L., \& Maloney, K. (2015). Standing by to help: Transforming online reference with a proactive chat system. The Journal of Academic Librarianship, 41(6), 764-770. http://doi.org/10.1016/j.acalib.2015.08.018

Maloney, K., \& Kemp, J. H. (2015). Changes in reference question complexity following the implementation of a proactive chat system: Implications for practice. College $\mathcal{E}$ Research Libraries, 76(7), 959-974. http://doi.org/10.586o/crl.76.7.959 
Martell, C. (2008). The absent user: Physical use of academic library collections and services continues to decline 1995-2006. The Journal of Academic Librarianship, 34(5), 400-407. http://doi.org/10.1016/j.acalib.2008.06.003

Oxford, E. (2016). Survey data: When what you see is not what you wanted to get. College E Research Libraries News, 77(5), 249-250. http://doi.org/10.1101/IntR-01-2014-0017.2.

Tucker, J. M. (1980). User education in academic libraries: A century in retrospect. Library Trends, 29(1), 9-27. Journal Article. Retrieved from http://hdl.handle.net/2142/7115

Yang, S. Q., \& Dalal, H. A. (2015). Delivering virtual reference services on the Web: An investigation into the current practice by academic libraries. The Journal of Academic Librarianship, 41(1), 68-86. http://doi.org/10.1016/j.acalib.2014.10.003 